\title{
УдК 316.4.066
}

С. С. Дембіиъкий, канд. соиіол. наук

Інститут соиіологї̈ НАН України

\section{ЧИННИКИ ЗАДОВОЛЕНОСТІ НАСЕЛЕННЯ ПРЕЗИДЕНТСЬКОЮ ВЛАДОЮ В УКРАЇНІ (2000-2012 РОКИ)}

Стаття присвячена трьом чинникам задоволеності президентською владою в Україні, а саме - очікуванням, спростуванню (порівняння очікувань й реальних результатів діяльності) й політичній позиції респондентів. Теоретичною базою дослідження використана модель Р. Олівера, а емпіричний аналіз здійснений за допомогою багатомірних регресійних рівнянь.

Ключові слова: задоволеність населення, соціологічний моніторинг, президент.

\section{Вступ}

Одним з головних завдань української соціології $є$ оцінка ефективності демократичних змін, що відбуваються в нашій державі. Зокрема це стосується й діяльності президентів України, що робить актуальним питання критеріїв відповідної оцінки, що ними керуються наші співгромадяни. Дослідження цього питання дозволить краще зрозуміти важливі особливості довгострокової взаємодії між президентською владою та населенням нашої держави.

Теоретико-методологічною базою аналізу є маркетингова модель для аналізу задоволеності споживачів, запропонована Ричардом Олівером [1]. Дана модель $є$ головним об'єктом уваги в представленому дослідженні, а отже ключове завдання - дослідження евристичних можливостей її використання для аналізу формування задоволеності політичними діячами.

Для вирішення окреслених завдань використані дані соціологічного моніторингового дослідження "Українське суспільство"1 .

\footnotetext{
${ }^{1}$ Проводиться Інститутом соціології НАНУ починаючи із 1994 року. Керівник проекту д.е.н., директор Інституту соціології НАНУ В.М.Ворона. Автор програми проекту д.с.н. Н.В. Паніна. Вибіркова сукупність кожного опитування в середньому становить 1800 осіб і репрезентує доросле населення України (віком понад 18 років). Головна мета моніторингу - аналіз тенденцій соціальних змін в українському суспільстві. Більш докладно див.: [2].
} 


\section{Теоретико-методологічна частина}

Нижче представлена концептуальна модель формування задоволеності споживачів Р. Олівера, адаптована до політичної сфери (див. рис. 1). Відмінностями від оригінальної моделі є заміна таких елементів: а) "товару/послуги" на "політика", б) "докупівельних умов" - на "політичні переконання", в) "акту придбання" - на "акт політичного вибору", що виражається у відповідному голосуванні на виборах. В іншому оригінальна та адаптована схеми є ідентичними.

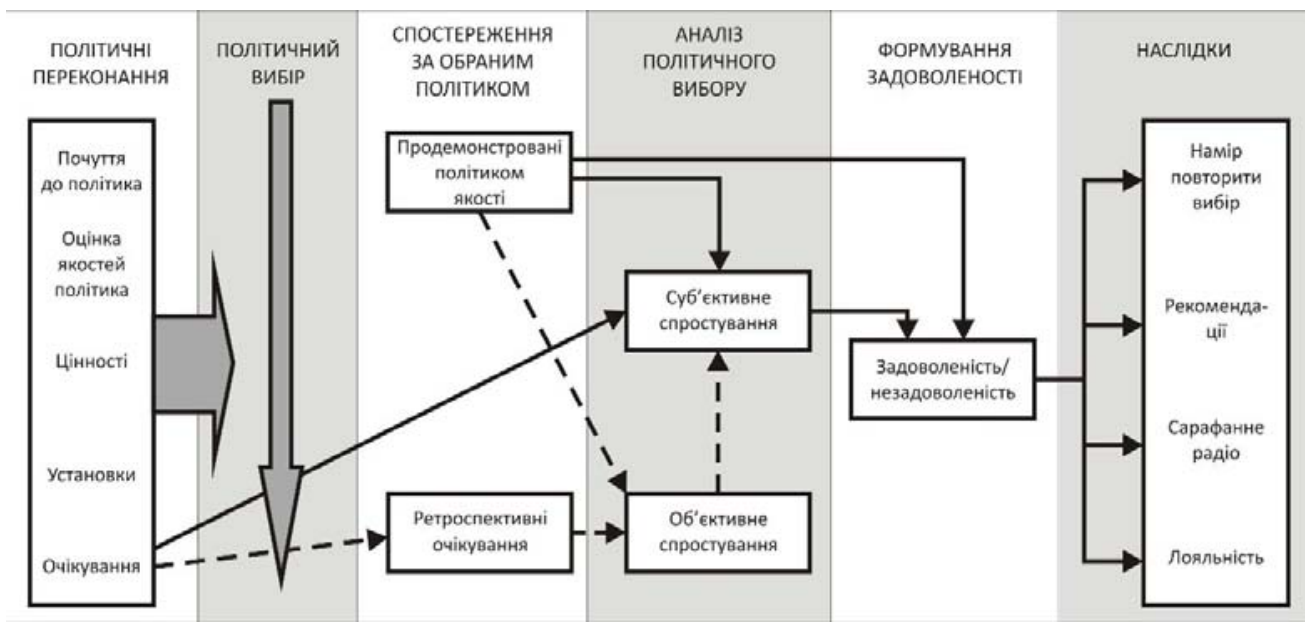

Рис. 1. Концептуальна модель формування задоволеності політичним діячем

3 даної схеми видно, що виборець проходить ряд етапів у своєму ставленні та діях стосовно політиків. На початку, у відповідності до своїх політичних переконань, головним з яких $є$ очікування, він здійснює політичний вибір. Незалежно від того, який 3 кандидатів прийшов до влади, виборець здійснює спостереження як за провладними, так і за опозиційними силами діями та якостями, які вони демонструють під час виконання своїх обов'язків. На основі цієї інформації та на основі очікувань (у тому числі і ретроспективних) здійснюється аналіз власного політичного вибору, що полягає в суб'єктивному та об'єктивному спростуванні.

Окремої уваги заслуговує поняття спростування. Воно виявляється у порівнянні очікувань 3 реально отриманими вигодами i, в залежності від результату, поділяється на негативне (діяльність політика розглядається як шкідлива), нейтральне (діяльність політика як не завдає шкоди, так і не приносить особливих вигод) та позитивне (діяльність обраного розглядається як продуктивна). Об'єктивне спростування має місце тоді, коли можливий розрахунок точної відмінності між очікуваною та отриманою величи- 


\section{СОЦІОЛОГІЯ}

ною вигод (наприклад, очікувана та реальна величина збільшення пенсії чи зарплатні). Суб'єктивне ж спростування полягає в суб'єктивній оцінці невідповідності між очікуваними та отриманими вигодами. Суб'єктивне спростування є більш вагомим фактором формування задоволеності. По-перше, об'єктивно однакові відмінності між очікуваннями та вигодами можуть порізному оцінюватися різними виборцями. По-друге, далеко не все піддається точній кількісній оцінці з боку звичайних виборців, отже не підлягає об'єктивному спростуванню взагалі (наприклад, стан свободи слова, дотримання прав людини тощо).

У результаті спростування формується задоволеність/незадоволеність споживачів, що, у свою чергу, призводить до відповідних наслідків.

$€$ й випадки, коли ключовим чинником формування задоволеності $\epsilon$ не спростування, а очікування. Це має місце у випадках, коли виборець не $\epsilon$ достатньо компетентним для того, щоб судити про діяльність політика (наприклад, щодо довгострокових економічних реформ), або просто не робить цього в практичному сенсі через відсутність інтересу (наприклад, оцінка внесених законопроектів, що передбачає постійний моніторинг законодавчої сфери).

Розглядаючи провідних вітчизняних політиків насамперед як політичні пропозиції на ринку товарів демократії, дана схема $є$ цілком адекватним керівництвом для проведення подальшого аналізу. Логічним додатком до неї є введення як ключового чинника, на рівні з очікуваннями та спростуванням, політичної позиції респондента (на схемі - це політичні переконання), особливо важливої в умовах політичної гетерогенності українського суспільства.

Для аналізу даних Р. Олівер рекомендує використовувати регресійні рівняння, що й обумовило вибір основного статистичного методу, а саме покрокової множинної регресії.

У свою чергу, відбір емпіричних індикаторів з моніторингу "Українське суспільство" (див. табл. 1) здійснювався з урахуванням двох критеріїв: відповідність основним елементам концептуальної моделі (політична позиція, очікування, спростування та задоволеність) та достатня сила зв'язку між ними.

Вибір індикаторів потребує декотрих пояснень. По-перше, рівень довіри президенту віднесено до очікувань, виходячи з того розуміння, яке вкладав у довіру Н. Луман. Зокрема, він вважав, що довіра являє собою очікування того, що контрагент буде діяти у відповідності до своєї соціальної ролі [3].

По-друге, концепт політичної позиції розглядається в тому числі і крізь призму протистояння східного (Партія регіонів) та західного ("Наша Україна", БЮТ) електорату, оскільки воно [протистояння] формує реалії української політики починаючи з 2004 р. і дотепер. 
Емпіричні індикатори концептуальної моделі формування

Таблиия 1 задоволеності політичним діячем²

\begin{tabular}{|c|l|}
\hline \multicolumn{1}{|c|}{ концепти } & \multicolumn{1}{|c|}{ Індикатори } \\
\hline \multirow{2}{*}{ Політична позиція } & $\begin{array}{l}\text { 1. Результати голосування респондента в другому турі } \\
\text { президентських виборів. } \\
\text { 2. Рівень підтримки лідерів помаранчевої революції. } \\
\text { 3. Рівень підтримки президента в області, в якій мешкає } \\
\text { респондент (спеціально створена змінна на основі даних про } \\
\text { результати голосування в останньому турі на виборах 1999, } \\
\text { 2004 та 2010 рр.). }\end{array}$ \\
\hline Очікування & $\begin{array}{l}\text { 1. Рівень довіри президенту. } \\
\text { 2. Позиція респондента щодо характеру змін у суспільному } \\
\text { житті: покращиться, погіршиться, не зміниться. }\end{array}$ \\
\hline Спростування & $\begin{array}{l}\text { Блок з 12 запитань щодо характеру соціальних змін, які } \\
\text { відбулися в житті респондента (питання не об'єднувалися } \\
\text { в індекс, а використовувалися як окремі індикатори). }\end{array}$ \\
\hline Задоволеність & Оцінка президента України за 10-бальною шкалою. \\
\hline
\end{tabular}

По-третє, змінна, що стосується результатів голосування у другому турі, приведена до порядкової шкали (перша градація - голосування за переможеного кандидата, друга - голосування проти обох, третя - голосування за кандидата-переможця). Можливість саме такого використання змінної підтверджується такими даними (див. табл. 2):

Таблиия 2

Рівень оцінки президента в залежності від позиції респондента під час останніх президентських виборів

\begin{tabular}{|c|c|c|c|}
\hline \multirow{2}{*}{ Рік } & \multicolumn{3}{|c|}{ Рівень оцінки президента за 10-бальною шкалою } \\
\cline { 2 - 4 } & $\begin{array}{c}\text { Тих, хто підтримував } \\
\text { його опонента на виборах }\end{array}$ & $\begin{array}{c}\text { Тих, хто не підтримував } \\
\text { ні його, ні його опонента } \\
\text { на виборах }\end{array}$ & $\begin{array}{c}\text { Тих, хто підтримував } \\
\text { його на виборах }\end{array}$ \\
\hline 2000 & 2,4 & 2,7 & 5,2 \\
\hline 2006 & 2,4 & 3,3 & 5,1 \\
\hline 2008 & 2,6 & 3,5 & 4,5 \\
\hline 2010 & 3,3 & 4,2 & 6,6 \\
\hline 2012 & 2,4 & 3,0 & 4,6 \\
\hline
\end{tabular}

${ }^{2}$ Точне формулювання питань наведено в додатку. 


\section{СОЦІОЛОГІЯ}

Представлені індикатори достатньо (принаймні щільніше за інші альтернативи) пов'язані між собою, а результати їх використання під час регресійного аналізу демонструють стійкі патерни протягом багатьох років, що є додатковим аргументом на їх використання.

\section{Емпірична частина}

Нижче представлено дані щодо кожного з чинників формування задоволеності діяльністю президентів у 2000, 2006, 2008 та 2012 рр. (див. табл. 3). У випадку президентства Л. Кучми береться 2000 р., оскільки він (перший рік після повторного обрання Л. Кучми) дає найбагатшу інформацію щодо очікувань, спростування та політичної позиції респондентів. Усі наведені в таблиці дані є статистично значимими на рівні $1 \%$.

Табличя 3

\section{Вплив очікування, політичної позиції та спростування на оцінку діяльності президента України}

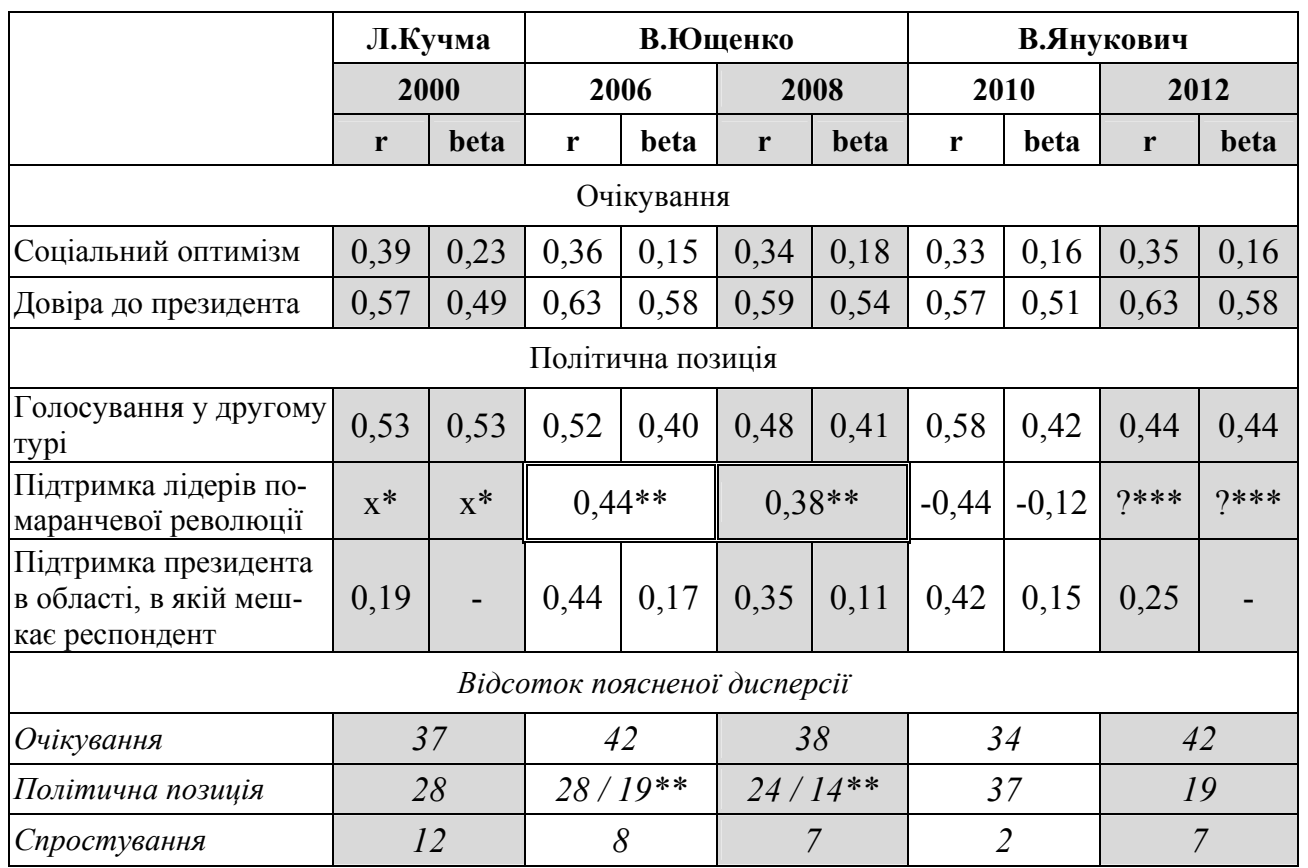

* Символ "х" позначає параметр якого не було у 2000 р.

** Для даних 2006 та 2008 рр. в частині політичної позиції можливо побудувати два регресійні рівняння 3 використанням як незалежних змінних або результатів голосування у другому турі та рівня підтримки президента в області, в якій мешкає респондент (більший пояснювальний потенціал), або рівня підтримки лідерів помаранчевої революції (менший пояснювальний потенціал).

*** Символ "?" позначає параметр, який не вимірювався у 2012 p. 
Для індикаторів, що входять до очікувань та політичної позиції, зазначено силу зв'язку з оцінкою діяльності президентів та стандартизовані коефіцієнти бета ${ }^{3}$. Для індикаторів, що входять до спростування, аналогічна інформація не наводиться, оскільки більшість відповідних коефіцієнтів хоча i є статистично значимими, але демонструють дуже малу силу зв'язку. Додатково для кожної групи індикаторів поданий відсоток поясненої нею дисперсії для оцінки діяльності президента (для кожної групи індикаторів будувалося окреме регресійне рівняння).

На основі представлених даних можна проаналізувати три базові моделі, які пояснюють оцінку діяльності президента:

a) "очікування => задоволеність", тобто орієнтація на перспективи, які пов'язуються респондентом з президентом України;

б) "політична позиція => задоволеність", тобто оцінка крізь призму узгодженості/неузгодженості політичних поглядів респондента й його оточення, $з$ одного боку, та президента - 3 іншого;

в) "спростування => задоволеність", тобто оцінка, виходячи з реальних результатів діяльності президента.

Очевидно, що найкращу пояснювальну силу має перша модель, а найгіршу - остання. Тобто респонденти орієнтуються перш за все на перспективи, які вони пов'язують з главою держави, слабший вплив справляє їх політичний вибір, а реальні зміни майже не беруться до уваги при оцінці діяльності президента (див. рис. 2).

Для аналізу впливу політичної позиції необхідні змінні (зокрема найважливіша 3 них - вибір респондента в другому турі президентських виборів) наявні лише в масивах 2000, 2006, 2008, 2010 та 2012 pр. Тому відповідна крива починається з 2000 р. Крапки позначають припущення, згідно з яким політична позиція пояснює приблизно 28\% мінливості в оцінці діяльності президента з 2001 по 2004 pp.

Звичайно немає ніяких принципових бар'єрів для інтегрованого розгляду окреслених чинників задоволеності президентською владою. Більш того, цілком логічно розглянути їх комбінований вплив. Нижче наведена найелементарніша шляхова діаграма ${ }^{4}$, що демонструє вплив політичної позиції та очікувань респондента на оцінку президента у 2012 році (див. рис. 3). До схеми включено лише три змінні: довіра до президента $\left(\mathrm{X}_{1}\right.$, репрезентує очікування), результати голосування в другому турі $\left(\mathrm{X}_{2}\right.$, репрезентує політичну позицію) та оцінка діяльності президента (Y). Інші змінні не включені до діа-

\footnotetext{
${ }^{3}$ Стандартизований коефіцієнт множинної регресії, що застосовується для порівняння результатів впливу різних незалежних змінних на залежну змінну.

${ }^{4}$ Шляхова діаграма обчислена за допомогою покрокової множинної регресії за припущення про відсутність помилок вимірювання (більш докладно див. [4, с. 118-135]). Величина біля двоспрямованої стрілки є значенням коефіцієнта кореляції Пірсона для відповідної пари змінних, величини біля односпрямованих стрілок - стандартизованими коефіцієнтами регресії для відповідних пар змінних.
} 


\section{СОЦІОЛОГІЯ}

грами, оскільки їх пояснювальний потенціал у даному випадку є мізерним і майже не змінює загальної картини.

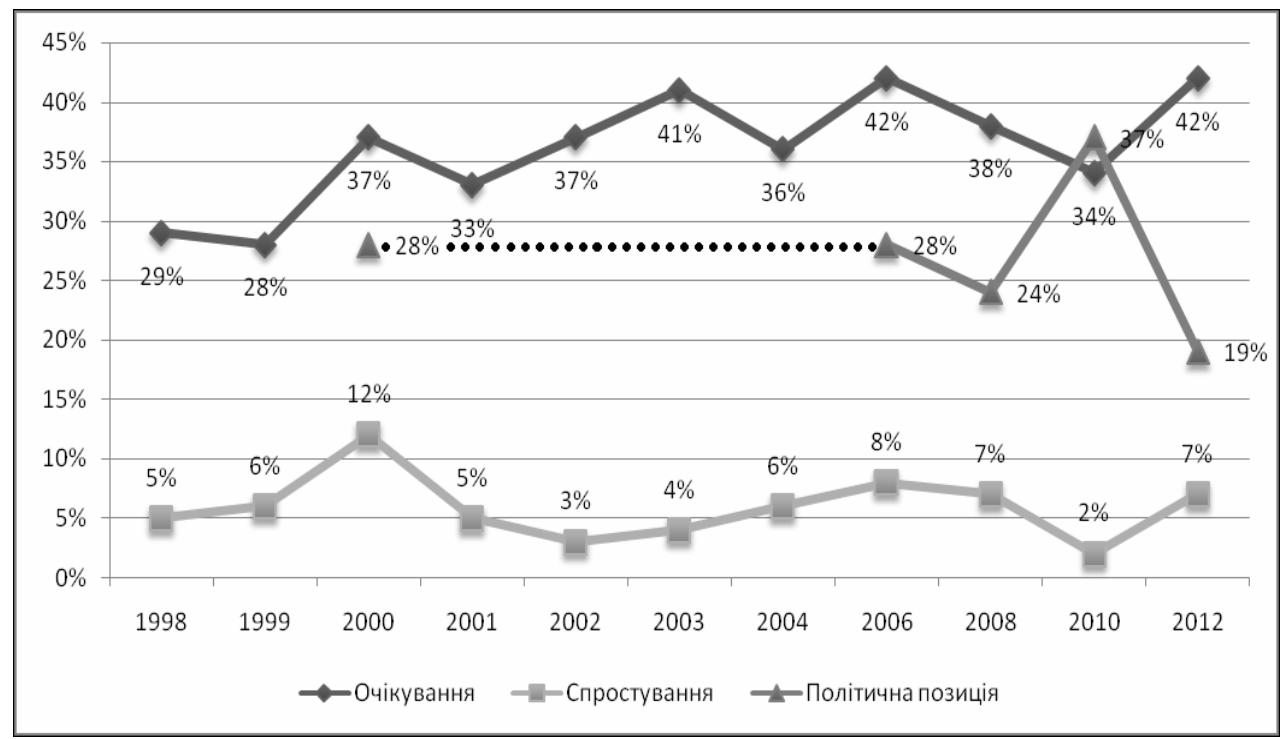

Рис. 2. Пояснювальна сила очікувань і спростування щодо оцінки діяльності президента України (1998-2012)

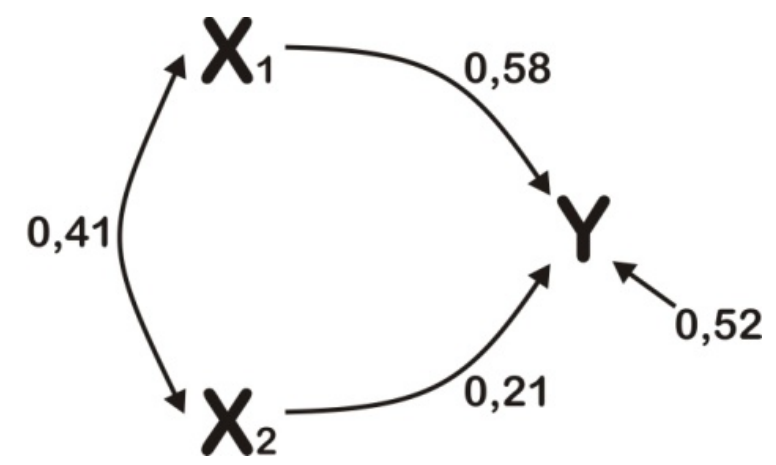

Рис. 3. Шляхова діаграма впливу очікувань та політичної позиції на оцінку діяльності президента

Пояснюючий потенціал даної діаграми становить 48\% (відповідно на залишки припадає 52\%), що більше від будь-якої базової моделі 2012 p.

\footnotetext{
${ }^{5}$ Відсоток поясненої дисперсії за 1998, 1999, 2001-2004 рр. обчислювався так само, як і для табл. 2.
} 
Утім аналіз, здійснений для України загалом, має специфічний зсув артефактним ефектом є міжрегіональна мінливість, що штучним чином збільшує відсоток дисперсії, поясненої регресійними рівняннями як для кожної з базових моделей, так і для інтегрованої моделі. Для перевірки впливу регіональної специфіки на оцінку відповідних взаємозв'язків був здійснений роздільний аналіз підгруп (окремо для Західного, Центрального, Південного та Східного регіонів) із застосуванням аналогічної методики аналізу. Далі наведено лише відсоток поясненої дисперсії для кожної групи індикаторів (див. табл. 4).

Таблиия 4

Вплив очікування, політичної позиції та спростування на оцінку діяльності президента України в різних регіонах

\begin{tabular}{|l|c|c|c|c|c|}
\hline \multirow{2}{*}{ Фактори } & Л.Кучма & \multicolumn{2}{c|}{ В.Ющенко } & \multicolumn{2}{c|}{ В.Янукович } \\
\cline { 2 - 6 } & $\mathbf{2 0 0 0}$ & $\mathbf{2 0 0 6}$ & $\mathbf{2 0 0 8}$ & $\mathbf{2 0 1 0}$ & $\mathbf{2 0 1 2}$ \\
\hline \multicolumn{7}{|c|}{ Захід } \\
\hline Очікування & 39 & 36 & 26 & 29 & 29 \\
\hline Політична позиція & 11 & 11 & 10 & 32 & 19 \\
\hline Спростування & 17 & 6 & 4 & 2 & 11 \\
\hline \multicolumn{7}{|c|}{ Центр } \\
\hline Очікування & 30 & 37 & 35 & 18 & 36 \\
\hline Політична позиція & 25 & 15 & 11 & 21 & 21 \\
\hline Спростування & 10 & 5 & 3 & 3 & 8 \\
\hline \multicolumn{7}{|c|}{ Південь } \\
\hline Очікування & 30 & 24 & 37 & 35 & 48 \\
\hline Політична позиція & 30 & 20 & 14 & 26 & 13 \\
\hline Спростування & 11 & 7 & 7 & 7 & 9 \\
\hline \multicolumn{7}{|c|}{ Схід } \\
\hline Очікування & 34 & 38 & 36 & 34 & 42 \\
\hline Політична позиція & 36 & 22 & 23 & 16 & 8 \\
\hline Спростування & 5 & 6 & 5 & - & 2 \\
\hline
\end{tabular}

Як видно, в меншості випадків відсоток поясненої дисперсії збільшився або залишився майже незмінним, а в більшості випадків - зменшився. I хоча головний патерн залишився той самий (у 15 з 20 випадків визначальне значення мають очікування, маргінальне - спростування), очевидною є і регіональна специфіка - прояв моделей у різних випадках носить специфічний характер, що говорить про можливість лише приблизних висновків на рівні усієї держави. 


\section{СОЦІОЛОГІЯ}

\section{Висновки}

Проведений аналіз продемонстрував евристичну ефективність моделі формування задоволеності споживачів Р.Олівера в межах дослідження оцінки діяльності президентів України. Результати виявили узгодженість за всіма роками, для яких була наявна можливість використання моделі.

Важливо зазначити головну відмінність із базовою (призначеною для дослідження звичайних товарів та послуг) моделлю - на рівні з очікуваннями та спростуванням релевантним фактором є політична позиція респондента, яка суттєво впливає на оцінку діяльності президента. В окремих випадках (як, наприклад, у 2010 р.) вона може виходити на перше місце серед усіх чинників формування задоволеності.

Останнє вказує на окремі особливості українського суспільства. Так, дуже цікавим $є$ те, що спростування відіграє, по суті, мізерну роль в оцінці діяльності президентів України. Фактично більшість пересічних громадян послуговуються в оцінці не реально досягнутими результатами, а новою "порцією" очікувань, що пов'язуються $з$ тим чи іншим президентом, а також узгодженістю (чи неузгодженістю) своїх політичних поглядів із поглядами, що ними декларуються.

Цілком можливо, що очікування "живляться", перш за все, узгодженістю чи неузгодженістю політичних поглядів. Це, у свою чергу, говорить про низький рівень політичної культури, ціннісну ангажованість та слабку громадянську складову нашого суспільства, а також створює усі умови для формування безвідповідальної політичної еліти.

1. Oliver R. Customer Satisfaction Research / Richard Oliver ; ed. By R. Grover, M. Vriens. // The Handbook of Marketing Research: Uses, Misuses, and Future Advances. - London, Thousand Oaks, New Delhi: Sage, 2006. - P. 569587.

2. Головаха $C$. Моніторинг соціальних змін в українському суспільстві / Євген Головаха, Наталія Паніна ; за ред. С. Макєєва // Структурні виміри сучасного суспільства. - К. : Ін-т соціології НАН України, 2006. - С. 162 189.

3. Luhman N. Familiarity, Confidence, Trust: Problems and Alternatives / Niklas Luhman ; ed. by D. Gambetta // Trust: Making and Breaking Cooperative Relations (electronic edition). - Oxford : University of Oxford, 2000. - P. 94-107.

4. Крамер Д. Математическая обработка данных в социальных науках: современные методы / Дункан Крамер. - М. : Издат. центр "Академия", 2007. $288 \mathrm{c}$. 
ISSN 1681-116X. Український соціум. 2012. № 3(42)

\section{Транслітерований список джерел}

1. Oliver R. Customer Satisfaction Research / Richard Oliver ; ed. By R. Grover, M. Vriens. // The Handbook of Marketing Research: Uses, Misuses, and Future Advances. - London, Thousand Oaks, New Delhi: Sage, 2006. - P. 569-587. [in English]

2. Golovaha Je. Monitoryng social'nyh zmin v ukrai'ns'komu suspil'stvi / Jevgen Golovaha, Natalija Panina ; za red. S.Makjejeva // Strukturni vymiry suchasnogo suspil'stva. - K. : In-t sociologii' NAN Ukrai'ny, 2006. - S. 162-189. [in Ukrainian]

3. Luhman N. Familiarity, Confidence, Trust: Problems and Alternatives / Niklas Luhman ; ed. by D. Gambetta. // Trust: Making and Breaking Cooperative Relations (electronic edition). - Oxford : University of Oxford, 2000. - P. 94-107. [in English]

4. Kramer D. Matematycheskaja obrabotka dannыh v socyal'nыh naukah: sovremennыe metodы / Dunkan Kramer. - M. : Yzdat. centr "Akademyja", 2007. $288 s$. [in Ukrainian] 


\section{СОЦІОЛОГІЯ}

Додаток

\section{Точне формулювання анкетних запитань}

1. Політична позиція.

1.1. Результати голосування респондента у другому турі президентських виборів 1999/2010 та 2004 років відповідно:

За кого Ви голосували у другому турі президентських виборів 1999/2010 року?

За кого Ви голосували у третьому (додатковому) турі президентських виборів 2004 року?

1.2. Рівень підтримки лідерів помаранчевої революції:

Чи підтримували Ви політичних лідерів "помаранчевої револючії" $і$ чи підтримуєте Ви їх зараз?

2. Очікування.

2.1. Рівень довіри президенту:

Який рівень Вашої довіри Президенту?

2.2. Позиція респондента щодо характеру змін в суспільному житті:

Як ви вважаєте, у найближчий рік наше життя більш або менш владнається чи жодного поліпшення не станеться?

3. Спростування.

Блок 312 запитань щодо характеру соціальних змін, які відбулися в житті респондента:

Як Ви оиінюєте характер змін, які відбулися у Вашому житті за останні 12 місяиів? Для відповіді по кожному рядку використовуйте такі оиінки:

1. Матеріальні умови сім'ї.

2. Медичне обслуговування.

3. Умови відпочинку під час відпустки.

4. Умови відпочинку та дозвілля після роботи.

5. Можливість отримання достовірної інформаиії про те, щуо діється у краӥні.

6. Умови виховання дітей.

7. Можливість вільно висловлювати власні погляди.

8. Можливість брати участь у культурному житті.

9. Екологічна ситуація (стан довкілля).

10. Захищеність від свавілля влади, посадовиів.

11. Гарантії зайнятості, забезпеченість роботою.

12. Особиста безпека (на вулииі, в громадських місиях).

4. Задоволеність.

Оцінка президента України за 10-бальною шкалою:

Яку оцінку Ви б дали оцінку діяльності Л.Кучми / В.Ющенка / В.Януковича на посаді Президента Украӥни, якщо "1" - найнижча, а "10" - найвища оиінка? 
Отримано 13.06.12

С.С. Дембиикий, канд. сочиол. наук

ФАКТОРЫ УДОВОЛЕТВОРЕНОСТИ НАСЕЛЕНИЯ ПРЕЗИДЕНТСКОЙ ВЛАСТЬЮ В УКРАИНЕ (2000-2012 гг.)

Статья посвящена трем факторам удовлетворенности президентской властью в Украине, а именно - ожиданиям, опровержению (сравнение ожиданий и реальных результатов деятельности) и политической позиции респондентов. В качестве теоретической базы исследования использована модель Р. Оливера, а эмпирический анализ осуществлен при помощи многомерных регрессионных уравнений.

Ключевые слова: удовлетворенность населения, социологический мониторинг, президент.

\section{S.S. Dembitskiy, Candidate of Sociological Sciences}

\section{FACTORS OF SATISFACTION OF THE POPULATION OF PRESIDENTIAL AUTHORITIES IN UKRAINE (2000-2012)}

This article is devoted to the three factors of satisfaction by presidential power in Ukraine - namely, the expectation refutation (comparison of expectations and actual performance) and political position of the respondents. As the theoretical basis for the study is used a model of R. Oliver and empirical analysis carried out using multivariate regression equations. dent.

Key words: satisfaction of the population, sociological monitoring, presi- 